\title{
PENGARUH BRAND IMAGE, LOKASI DAN STORE ATMOSPHERE TERHADAP PROSES KEPUTUSAN PEMBELIAN KONSUMEN PADA MINIMARKET “KEDAI YATIM”
}

\section{THE INFLUENCE OF BRAND IMAGE, LOCATION AND STORE ATMOSPHERE TO CONSUMER PURCHASING DECISION PROCESS ON MINIMARKET "KEDAI YATIM"}

\author{
M.Z. Fikri'1a; A.S. Mulazid² \\ 1aFakultas Ekonomi dan Bisnis, UIN Syarif Hidayatullah Jakarta, E-mail: \\ zainulfikri72@gmail.com \\ 2Fakultas Ekonomi dan Bisnis, UIN Syarif Hidayatullah Jakarta, E-mail: \\ adesofyanmulazid@uinjkt.ac.id
}

\begin{abstract}
The purpose of this research is to analyze the influence of brand image, location and store atmosphere to consumer purchasing decision process on minimarket "Kedai Yatim". This type of research is quantitative. The data source of this study is the primary data derived from the sample of consumers minimarket "Kedai Yatim". Data collection was done by distributing questionnaires to 100 respondents. This research uses Multiple Regression analysis method. The results of this research showed that : (1) the brand image significantly influences consumer purchasing decision process in minimarket "Kedai Yatim" (2) location has significant effect to consumer purchasing decision process at minimarket "Kedai Yatim" (3) store atmosphere significantly affect consumer purchasing decision process at minimarket "Kedai Yatim", and (4) brand image, location and store atmosphere significantly influence consumer purchasing decision process at minimarket "Kedai Yatim".
\end{abstract}

Keywords: Brand Image, Location, Store Atmosphere, Purchase Decision Process

\begin{abstract}
ABSTRAK
Tujuan penelitian ini adalah untuk menganalisis pengaruh brand image, lokasi dan store atmosphere terhadap proses keputusan pembelian konsumen pada minimarket "Kedai Yatim". Jenis penelitian ini adalah kuantitatif. Sumber data penelitian ini merupakan data primer yang berasal dari sampel yaitu konsumen minimarket "Kedai Yatim". Pengumpulan data dilakukan dengan menyebarkan kuesioner kepada 100 responden. Penelitian ini menggunakan metode analisis Regresi Berganda. Hasil temuan dari penelitian ini menunjukkan bahwa: (1) brand image berpengaruh secara signifikan terhadap proses keputusan pembelian konsumen pada minimarket "Kedai Yatim" (2) lokasi berpengaruh secara signifikan terhadap proses keputusan pembelian konsumen pada minimarket "Kedai Yatim" (3) store atmosphere berpengaruh secara signifikan terhadap proses keputusan pembelian konsumen pada minimarket "Kedai Yatim", dan (4) brand image, lokasi dan store atmosphere berpengaruh secara signifikan terhadap proses keputusan pembelian konsumen pada minimarket "Kedai Yatim".
\end{abstract}

Kata Kunci : Brand Image, Lokasi, Store Atmosphere, Proses Keputusan Pembelian 
Fikri, Muhammad Zainul. 2018. Pengaruh Brand Image Lokasi, dan Store Atmosphere Terhadap Proses Keputusan Pembelian Konsumen Pada Minimarket "Kedap Yatim". Jurnal Syarikah 4 (1): 22-32.

\section{PENDAHULUAN}

Bisnis ritel merupakan aktivitas bisnis yang melibatkan penjualan barang dan jasa secara langsung kepada konsumen akhir. Pada perkembangannya, bisnis ritel di Indonesia sendiri mulai bertransformasi dari bisnis ritel tradisional menjadi bisnis ritel modern. Perkembangan bisnis ritel modern sendiri di Indonesia sudah semakin menjamur hampir di seluruh wilayah Indonesia. Jika dilihat sekarang pasti banyak supermarket atau minimarket di desa-desa atau perkampungan. Hal ini terjadi karena perilaku atau kebiasaan orang-orang yang dahulunya sering berbelanja dipasar tradisional namun sekarang lebih senang berbelanja di minimarket atau supermarket yang lebih praktis dan nyaman. Fenomena ini pun langsung dimanfaatkan oleh produsen lainnya untuk membuat toko-toko retail berbasis minimarket dan lainnya untuk menarik perhatian dan minat konsumen untuk mengubah kebiasaan berbelanja para konsumen.

Industri ritel modern (modern trade) untuk kategori fast moving consumer goods (FMCG) di Indonesia tumbuh rata-rata $10,8 \%$ pada 2015 , dengan pertumbuhan tertinggi terjadi pada bidang minimarket sebesar 11\% dan supermarket serta hypermarket sebesar 10,6\%. Penjualan toko modern per kapita di Indonesia diperkirakan mencapai US\$ 60 dengan komposisi 56\% pada minimarket dan $44 \%$ pada supermarket dan hypermarket.

Potensi bisnis minimarket Indonesia 2017 sepertinya akan lebih baik dibandingkan dengan tahun lalu. Karena para pengusaha retail mematok pertumbuhan bisnis ritel Indonesia mencapai $12 \%$. Jika dilihat merunut data Aprindo pertumbuhan retail 2016 berada diangka 10\% lebih baik dari 2015 yang hanya mencapai 8\%. Salah satu jenis usaha ritel yang masaih sangat prospektif adalah adalah minimarket, alasanya tentu karena perbaikan kondisi ekonomi yang di proyeksikan mencapai 5,3\%. Omzet ritel modern nasional pada 2016 diperkirakan tumbuh mencapai 10\%. Asosiasi Pengusaha Ritel Indonesia (Aprindo) memperkirakan nilai penjualan ritel modern 2016 mencapai 200 triliun dan jika di kombinasikan dengan makanan serta minuman olahan maka secara keseluruhan total mencapai 1.630 triliun.

Minimarket Kedai Yatim merupakan salah satu perusahaan yang bergerak pada bidang ritel yang menjual berbagai jenis produk-produk seperti yang dijual pada toko retail umumnya. Awal mula beridirinya Kedai Yatim itu pada bulan April tahun 2015 yaitu cabang pertama yang berada diciputat tepatnya di komplek Dep.Agama Bambu Apus. Uniknya karena konsep Islami yang diusung oleh toko Kedai Yatim ini tidak menjual rokok, alat kontrasepsi, miras (alcohol) yang menjadi kekuatan seperti yang diperjual-belikan retail-retail lainnya. Hadir dengan nama dan konsep yang menarik, banyak pelanggan dan konsumen mengira kedai yatim bukanlah minimarket melainkan seperti panti asuhan atau lembaga yang mengurus atau berkaitan dengan anak yatim karena dengan nama Kedai Yatim tersebut.

Kedai Yatim didirikan untuk mengembangkan bisnis ritel modem dengan melibatkan unsur ibadah yaitu melalui sedekah seperti terlihat dengan tagline yang mereka usung "Belanja Anda, Sedekah Anda". Maksudnya dengan 
berbelanja di kedai Yatim, pelanggan dan masyarakat selain memenuhi kebutuhan pokoknya sehari-hari juga bisa langsung bersedekah dengan belanjaan yang dibeli serta juga turut memiliki peran yang besar dalam membantu delegasi tiga kaum yang terdiri dari anak yatim, fakir miskin, dissable dari kalangan tidak mampu dengan cara menyalurkan sebanyak 30\% (tiga puluh persen) dari keuntungan bisnis ritel modern Kedai Yatim dan dilaporkan secara berkala.

Berdasarkan topbrand-award.com, pada bidang minimarket top brand index sebagian besar dikuasai oleh 2 nama besar yang sudah punya nama dalam bisnis ritel minimarket yaitu Alfamart dan Indomaret. Sekitar 93,4\% pasar minimarket didominasi oleh dua nama besar tersebut, berarti masih ada sekitar $6,6 \%$ pasar minimarket baru yang sedang merintis dan minimarket yang baru memiliki sedikit cabang serta baru dikenal namanya dimasyarakat. Disinilah Kedai Yatim berada dibagian yang hanya memiliki beberapa persen dari pangsa pasar minimarket, karena kedai yatim sendiri minimarket baru yang sedang merintis untuk dapat menjadi pembeda dan memberi variasi diantara minimarket lainnya. Top brand mampu memberikan ukuran kesuksesan sebuah merek di pasar melalui tiga pengukuran dimensi, yaitu mind share (top of mind), market share (last usage), dan commitment share (future intention).

Salah satu strategi yang tepat untuk meraih keunggulan bersaing dalam mempengaruhi keputusan konsumen adalah dengan membentuk brand image (citra merek) di dalam benak konsumen. Strategi ini mampu melawan persaingan dalam bidang pemasaran untuk dapat bertahan dan survive dalam memasarkan produknya ke konsumen. Brand image telah menjadi elemen krusial yang berkontribusi terhadap kesuksesan sebuah organisasi pemasaran. Maka perusahaan harus dapat menciptakan merek yang menarik sekaligus menggambarkan manfaat produk yang sesuai dengan keinginan dan kebutuhan konsumen sehingga dengan demikian konsumen memiliki citra yang positif terhadap merek. Memiliki citra merek yang kuat merupakan suatu keharusan bagi setiap perusahaan. Karena citra merek merupakan aset perusahaan yang sangat berharga.

Setelah konsumen percaya terhadap suatu merek secara pasti mereka akan senang dan sering berbelanja disana. Hal ini juga akan semakin baik jika lokasi toko sendiri yang tidak jauh dari keberadaan konsumen dan mudah dijangkau. Industri retail memiliki bauran pemasaran (marketing mix) yang salah satunya itu adalah lokasi. Lokasi yang nyaman, aman, bersih, ramai, dan mudah dijangkau beberapa kriteria lokasi yang banyak diminati konsumen. Faktor lokasi merupakan faktor penting yang harus diperhatikan khususnya pada perusahaan ritel, yang dapat mempengaruhi keputusan pembelian.

Selain brand image dan lokasi yang dapat mempengaruhi keputusan pembelian konsumen terutama pada toko atau store ritel yang baru muncul dan berkembang, ada faktor lain yang mendukung dalam berbisnis ritel yaitu store atmosphere. Store atmosphere dapat menjadi alasan konsumen memilih suatu toko. Karena konsumen atau pembeli akan melihat dari suasana toko juga disaat berbelanja kebutuhannya. Apakah suasana yang diciptakan toko nyaman sehingga bisa memanjakan pelanggannya disaat mereka sedang berbelanja.

Dengan konsep bisnis yang berbeda dengan retail lainnya maka penelitian ini akan menguji faktor-faktor yang mempengaruhi keputusan pembelian konsumen Kedai Yatim, diantaranya adalah: brand image, lokasi dan store atmosphere. 


\section{MATERI DAN METODE}

\section{Brand Image}

Brand image adalah persepsi konsumen mengenai sebuah merek, yang tercermin dari asosiasi merek yang berada di benak konsumen. Dengan kata lain, asosiasi merek adalah node informasi lain yang terhubung ke node merek dalam memori dan mengandung arti merek bagi konsumen. Asosiasi datang dalam segala bentuk dan mungkin mencerminkan karakteristik dari produk atau aspek independent dari produk (Keller, 2013:76).

\section{Lokasi}

Menurut Kotler dan Armstrong (2014:76), tempat meliputi kegiatan perusahaan yang membuat produk tersedia bagi pelanggan sasaran. Fungsinya memudahkan calon konsumen untuk mendapatkan produk yang ditawarkan.

\section{Store Atmosphere}

Store Atmosphere menurut Levy dan Weitz (2007:510) yaitu "Atmospherics refers to the design of an environment via visual communication, lighting, colors, music and scent to stimulate customers' perceptual and emitional responses and ultimately to affect their purchase behavior". Maksud dari pengertian tersebut adalah mendisain suatu lingkungan melalui komunikasi visual, pencahayaan, warna, musik dan penciuman untuk merangsang persepsi dan emosi dari pelanggan dan pada akhirnya untuk mempengaruhi perilaku pembelanjaan mereka.

\section{Proses Keputusan Pembelian}

Menurut Kotler dan Keller (2009:184), keputusan pembelian adalah tahap dalam proses pengambilan keputusan pembeli dimana konsumen benar-benar membeli. Pengambilan keputusan merupakan suatu kegiatan individu yang secara langsung terlibat dalam mendapatkan

dan mempergunakan barang yang ditawarkan.

\section{Penelitian Terdahulu}

Marchall, dkk (2015) melakukan penelitian tentang "The Influence of Brand Equity, Store Atmosphere And Consumer Attitudes Towards Purchase Decision of Fashionable Clothes AT 3 Second Manado Town Square". Hasil analisis data store atmosphere diperoleh nilai 0,$718 ; \mathrm{t}$ hitung=8,266; dan signifikansi $\mathrm{t}=0,000$. Hal ini menunjukkan variabel store atmosphere mempunyai nilai terbesar dalam mempengaruhi keputusan pembelian konsumen pada tempat yang diteliti.

Hasil penelitian yang dilakukan oleh Imelda Yuliana, 2016 tentang Pengaruh Kualitas Layanan, Citra Merek, dan Lokasi Terhadap Keputusan Pembelian pada Dunkin Donut's basuki rahmat Surabaya yaitu, citra merek berpengaruh positif terhadap keputusan pembelian, hal ini dibuktikan dengan nilai signifikansi sebesar 0,000 (sig 2,000) dan lokasi berpengaruh positif terhadap keputusan pembelian, dengan nilai signifikansi sebesar 0,044 .

\section{Perumusan Hipotesis}

Hipotesis merupakan jawaban sementara terhadap rumusan masalah penelitian, dimana rumusan masalah penelitian telah dinyatakan dalam bentuk pertanyaan. (Sugiyono,2011: 64).

Adapun perumusan hipotesis atas pengujian yang dilakukan disini adalah:

1) Hipotesis pengaruh secara simultan (bersama-sama) :

a. $H_{0}: \beta_{1}, \beta_{2}, \beta_{3}=0$ tidak ada pengaruh yang signifikan antara brand image, lokasi, store atmosphere terhadap keputusan pembelian.

b. $H_{a}: \beta_{i}, \beta_{2}, \beta_{3} \neq 0$ Ada pengaruh yang signifikan antara brand image, lokasi, store atmosphere terhadap keputusan pembeli.

2) Hipotesis secara parsial dari masingmasing variabel yang diteliti terhadap keputusan pembelian sebagai berikut: 
a. $\mathrm{H}_{0}: \beta_{1}=0$ tidak ada pengaruh yang signifikan antara brand image terhadap keputusan pembelian .

$\mathrm{H}_{\mathrm{a}}: \beta_{1} \neq 0$ ada pengaruh yang signifikan antara brand image terhadap keputusan pembelian .

b. $\mathrm{H}_{0}: \beta_{2}=0$ tidak ada pengaruh yang signifikan antara lokasi terhadap keputusan pembelian.

$H_{a}: \beta_{2} \neq 0$ ada pengaruh yang signifikan antara lokasi terhadap keputusan pembelian.

c. $\mathrm{H}_{0}: \beta_{3}=0$ tidak ada pengaruh yang signifikan antara store atmosphere terhadap keputusan pembelian.

$\mathrm{H}_{\mathrm{a}}: \beta_{3} \neq 0$ ada pengaruh yang signifikan antara store atmosphere terhadap keputusan pembelian.

\section{Jenis Penelitian}

Penelitian ini menggunakan pendekatan kuantitatif. Metode penelitian kuantitatif dapat diartikan sebagai metode penelitian yang berlandaskan pada filsafat positivisme. Penelitian kuantitatif digunakan untuk meneliti pada populasi atau sampel tertentu dimana penelitian mengambil sampel dari suatu populasi. Metode survey digunakan untuk mendapatkan data dari tempat tertentu yang alamiah atau bukan buatan. Peneliti melakukan pengumpulan data, misalnya dengan mengedarkan kuesioner, test, wawancara terstruktur dan lain sebagainya (Sugiyono, 2011:17).

Penelitian ini dilakukan di lokasi penelitian dengan menyebarkan kuesioner online dan langsung kepada responden yang memenuhi syarat tertentu. Waktu penelitian dilakukan dari bulan juni 2017, adapun yang akan dibahas yaitu mengenai seberapa besar pengaruh brand image, lokasi, dan store atmosphere terhadap keputusan pembelian pada minimarket Kedai Yatim. Variabel yang diteliti pada penelitian ini terdiri dari 4 (empat) variabel, yaitu variabel independen dan variabel dependen. Variabel independen pada penelitian ini adalah brand image (X1), lokasi (X2), dan store atmosphere (X3). Sedangkan variabel dependennya adalah keputusan pembelian (Y).

\section{Metode Pengumpulan Sampel}

Teknik yang digunakan dalam pengambilan sampel pada penelitian ini adalah Convenience/Accidental Sampling, accidental sampling yaitu teknik penentuan sampel berdasarkan kebetulan/insindental bertemu dengan peneliti dapat digunakan sebagai sampel, bila dipandang orang yang kebetulan ditemui cocok sebagai sumber data (Sugiyono, 2011:85).

\section{Metode Analisis Data}

Data yang telah dikumpulkan tersebut dapat bermanfaat maka harus diolah dan dianalisis terlebih dahulu sehingga dapat dijadikan sebagai dasar dalam pengambilan keputusan. Analisis data yang digunakan dalam penelitian ini adalah.

1. Uji Validitas dan Reliabilitas

Menurut Ghozali (2016:52) Uji validitas digunakan untuk mengukur sah atau valid tidaknya suatu kuesioner. Suatu kuesioner dikatakan valid jika pertanyaan pada kuesioner mampu untuk mengungkapkan sesuatu yang akan diukur oleh kuesioner tersebut.. Jadi, uji validitas ingin mengukur apakah pertanyaan dalam kuesioner sudah benar dapat mengukur apa yang hendak kita ukur. Menurut Ghozali (2016:47) menyatakan bahwa uji Reliabilitas adalah alat untuk mengukur suatu kuesioner yang merupakan indikator dari variabel atau konstruk. Suatu kuesioner dikatakan reliabel atau handal jika jawaban seseorang terhadap pernyataan adalah konsisten atau stabil dari waktu ke waktu.

2. Uji Asumsi Klasik

a. Uji Normalitas

Menurut Ghozali (2016:154) uji normalitas adalah menguji sebuah 
variabel bebas memiliki distribusi data yang normal atau tidak.

b. Uji Multikolonieritas

Uji Multikolonieritas bertujuan untuk menguji apakah model regresi ditemukan adanya korelasi antar variabel bebas (independen) (Ghozali,2011:105).

c. Uji Heteroskedastisitas

Uji Heteroskedastisitas bertujuan untuk menguji apakah dalam model regresi terjadi ketidaksamaan Variance dari residual satu pengamatan ke pengamatan yang lain.

3. Analisis Regresi Linear Berganda

Menurut Ghozali (2011:96), dalam analisis regresi, selain mengukur kekuatan hubungan antara dua variabel atau lebih , juga menunjukkan arah hubungan antara dua variabel atau lebih, juga menunjukkan arah hubungan antara variabel dependen dengan variabel independen.

4. Uji Hipotesis

a. Uji t Hitung dengan Uji Parsial

Uji Statistik $t$ pada dasarnya menunjukan seberapa jauh pengaruh variabel penjelas atau independen secara individual dalam menerangkan variasi variabel dependen (Ghozali, 2011).

b. Uji F Hitung (Uji simultan)

Salah satu cara melakukan uji F adalah dengan membandingkan nilai $\mathrm{F}$ hasil perhitungan dengan nilai $\mathrm{F}$ menurut tabel. Bila nilai $\mathrm{F}$ hitung besar daripada nilai $\mathrm{F}$ tabel, maka kita menerima hipotesis alternatif yang menyatakan bahwa semua variabel independen secara simultan mempengaruhi variabel dependen (Ghozali,2011).

5. Koefisien Determinasi (R2)

Koefisien determinasi $\left(\mathrm{R}^{2}\right)$ pada intinya mengukur seberapa jauh kemampuan model (ikatan, empati, timbal balik, dan kepercayaan) dalam menerangkan variasi variabel dependen /terikat (kepuasan pelanggan).

\section{Operasional Variabel Penelitian}

Variabel-variabel dalam penelitian ini yang terdiri dari 3 Variabel independen $(\mathrm{X})$, yaitu: brand image $\left(X_{1}\right)$, lokasi $\left(X_{2}\right)$, store atmosphere $\left(X_{3}\right)$. Sebaliknya, variabel dependen $(Y)$ hanya satu variabel yaitu keputusan pembelian.

\section{HASIL DAN PEMBAHASAN}

\section{Hasil Uji Validitas}

Tabel 1.

Hasil Uji Validitas Brand Image

\begin{tabular}{|c|c|c|c|}
\hline Pernyataan & $\begin{array}{c}\mathbf{r} \\
\text { hitung }\end{array}$ & $\begin{array}{c}\mathbf{r} \\
\text { tabel }\end{array}$ & Keterangan \\
\hline BI1 & 0,933 & 0,361 & Valid \\
\hline BI2 & 0,894 & 0,361 & Valid \\
\hline BI3 & 0,862 & 0,361 & Valid \\
\hline BI4 & 0,711 & 0,361 & Valid \\
\hline
\end{tabular}

Sumber : data diolah dengan SPSS 24.0 2017

Tabel di atas menunjukkan bahwa variabel brand image memiliki kriteria valid untuk semua item pernyataan berdasarkan kriteria $r$ hitung lebih besar dari $r$ tabel 0,361.

\section{Tabel 2}

Hasil Uji Validitas Lokasi

\begin{tabular}{|c|c|c|c|}
\hline Pernyataan & $\begin{array}{c}\text { r } \\
\text { hitung }\end{array}$ & r tabel & Keterangan \\
\hline L1 & 0,766 & 0,361 & Valid \\
\hline L2 & 0,845 & 0,361 & Valid \\
\hline L3 & 0,735 & 0,361 & Valid \\
\hline L4 & 0,642 & 0,361 & Valid \\
\hline L5 & 0,668 & 0,361 & Valid \\
\hline L6 & 0,845 & 0,361 & Valid \\
\hline
\end{tabular}

Sumber : data diolah dengan SPSS 24.0, 2017

Tabel 2 menunjukan bahwa variabel lokasi memiliki kriteria valid untuk semua item pernyataan berdasarkan kriteria $r$ hitung lebih besar dari $r$ tabel 0,361 . 
Tabel 3

Hasil Uji Validitas Store Atmosphere

\begin{tabular}{|c|c|c|c|}
\hline Pernyataan & $\begin{array}{c}\mathbf{r} \\
\text { hitung }\end{array}$ & $\begin{array}{c}\mathbf{r} \\
\text { tabel }\end{array}$ & Keterangan \\
\hline SA1 & 0,699 & 0,361 & Valid \\
\hline SA2 & 0,821 & 0,361 & Valid \\
\hline SA3 & 0,633 & 0,361 & Valid \\
\hline SA4 & 0,788 & 0,361 & Valid \\
\hline SA5 & 0,833 & 0,361 & Valid \\
\hline SA6 & 0,831 & 0,361 & Valid \\
\hline SA7 & 0,666 & 0,361 & Valid \\
\hline SA8 & 0,664 & 0,361 & Valid \\
\hline SA9 & 0,602 & 0,361 & Valid \\
\hline SA10 & 0,796 & 0,361 & Valid \\
\hline
\end{tabular}

Sumber : data diolah dengan SPSS 24.0 2017

Tabel 3 menunjukan bahwa variabel store atmosphere memiliki kriteria valid untuk semua item pernyataan berdasarkan kriteria $r$ hitung lebih besar dari $r$ tabel 0,361.

Tabel 4

Hasil Uji Validitas Keputusan Pembelian

\begin{tabular}{|c|c|c|c|}
\hline Pernyataan & $\begin{array}{c}\mathbf{r} \\
\text { hitung }\end{array}$ & $\begin{array}{c}\mathbf{r} \\
\text { tabel }\end{array}$ & Keterangan \\
\hline KPEM1 & 0,873 & 0,361 & Valid \\
\hline KPEM2 & 0,859 & 0,361 & Valid \\
\hline KPEM3 & 0,840 & 0,361 & Valid \\
\hline KPEM4 & 0,810 & 0,361 & Valid \\
\hline KPEM5 & 0,789 & 0,361 & Valid \\
\hline
\end{tabular}

Sumber : data diolah dengan SPSS 24.0, 2017

Tabel 4 menunjukan bahwa variabel keputusan pembelian memiliki kriteria valid untuk semua item pernyataan berdasarkan kriteria $r$ hitung lebih besar dari $r$ tabel 0,361.

\section{Hasil Uji Reliabilitas}

Tabel 5

Hasil Uji Reliabilitas

\begin{tabular}{|c|c|c|l|}
\hline Variabel & $\begin{array}{c}\text { Croncach's } \\
\text { Alpha }\end{array}$ & $\begin{array}{c}\text { N of } \\
\text { Items }\end{array}$ & Keterangan \\
\hline Brand Image & 0,867 & 4 & Reliabel \\
\hline Lokasi & 0,846 & 6 & Reliable \\
\hline $\begin{array}{c}\text { Store } \\
\text { Atmosphere }\end{array}$ & 0,904 & 10 & Reliable \\
\hline $\begin{array}{l}\text { Keputusan } \\
\text { Pembelian }\end{array}$ & 0,792 & 5 & Reliable \\
\hline
\end{tabular}

Sumber: data diolah dengan SPSS 24.0, 2017

Tabel 5 menunjukkan hasil nilai Cronbach's Alpha atas keempat variabel diatas mempunyai nilai yang lebih besar dari 0,70. Dengan demikian, dapat disimpulkan bahwa pertanyaan dalam kuesioner ini reliable.

\section{Hasil Uji Hipotesis}

Pengujian hipotesis digunakan untuk mengetahui ada atau tidaknya pengaruh antar variabel independen terhadap variabel dependen, adapun hasil pengujian adalah sebagai berikut:

\section{a. Hasil Uji Signifikan Simultan (Uji F)}

Uji statistik $F$ digunakan untuk memenuhi semua pengaruh variabel independen yang diuji pada tingkat signifikan 5\%. Hasil uji koefisien signifikan simultan dapat dilihat pada tabel berikut:

Tabel 6

\section{Hasil Uji Signifikan Simultan (Uji F)}

\begin{tabular}{|c|c|c|}
\hline Model & $\mathbf{F}$ & Sig. \\
\hline $\begin{array}{c}1 \text { Regression } \\
\text { Residual } \\
\text { Total }\end{array}$ & 16.467 & $.000^{b}$ \\
\hline
\end{tabular}

Sumber : data diolah dari SPSS 24.0, 2017

Berdasarkan data pada tabel 6 diatas, dapat diketahui nilai $\mathrm{F}$ hitung $16,467>\mathrm{F}$ tabel 2,70, dengan tingkat signifikan $0,000<0,05$. Sehingga hipotesis yang berbunyi terdapat pengaruh antara brand image, lokasi, dan store atmosphere secara simultan terhadap keputusan pembelian diterima (Ha diterima dan $\mathrm{H}_{0}$ ditolak), Dengan kata lain dapat dikatakan bahwa variabel brand image, lokasi, dan store atmosphere secara bersama-sama (simultan) berpengaruh signifikan terhadap variabel keputusan pembelian.

\section{b. Hasil Uji Signifikan Parsial (uji t)}

Pengujian hipotesis secara parsial dimaksudkan untuk mengetahui ada atau tidaknya pengaruh variabel bebas secara 
parsial terhadap variabel terikat. Hasil hipotesis dalam pengujian ini adalah sebagai berikut:

Tabel 7

Hasil Uji Signifikan Parsial (Uji t)

\begin{tabular}{|l|l|l|}
\hline Model & T & Sig. \\
\hline (Constant) & 1.057 & .293 \\
\hline Brand_Image & 3.664 & .000 \\
\hline Lokasi & 3.438 & .001 \\
\hline Store_Atmosphere & 3.501 & .001 \\
\hline
\end{tabular}

Sumber : data diolah dari SPSS 24.0, 2017

Berdasarkan pada tabel hasil Uji $t$ di atas untuk mengetahui besarnya pengaruh masing-masing variabel independen secara parsial (individual) terhadap variabel dependen adalah sebagai berikut:

a. Pengaruh Pengaruh Variabel Brand Image $\left(\mathrm{X}_{1}\right)$ terhadap Keputusan Pembelian (Y)

Pada tabel 7 nilai t hitung untuk brand image sebesar 3,664 sedangkan nilai $t$ tabel sebesar 1,988. Maka dapat diketahui t hitung 3,664 > t tabel 1,988 dan nilai signifikan $0,000<0,05$. Sehingga hipotesis yang berbunyi terdapat pengaruh yang signifikan antara brand image terhadap keputusan pembelian diterima $\left(\mathrm{H}_{\mathrm{a}}\right.$ diterima dan $\mathrm{H}_{0}$ ditolak), artinya secara parsial terdapat pengaruh yang signifikan antara brand image terhadap keputusan pembelian.

b. Pengaruh Variabel Lokasi $\left(\mathrm{X}_{2}\right)$ terhadap Keputusan Pembelian (Y)

Pada tabel 7 nilai t hitung untuk lokasi sebesar 3,438 sedangkan nilai $t$ tabel sebesar 1,988. Maka dapat diketahui t hitung 3,438 > t tabel 1,988 dan nilai signifikan $0,001<0,05$. Sehingga hipotesis yang berbunyi terdapat pengaruh yang signifikan antara lokasi terhadap keputusan pembelian diterima $\left(\mathrm{H}_{\mathrm{a}}\right.$ diterima dan $\mathrm{H}_{\mathrm{o}}$ ditolak), artinya secara parsial terdapat pengaruh yang signifikan antara lokasi terhadap proses keputusan pembelian. c. Pengaruh Variabel Store Atmosphere $\left(\mathrm{X}_{3}\right)$ terhadap Keputusan Pembelian (Y)

Pada tabel 7 nilai t hitung untuk store atmosphere sebesar 3,501 sedangkan nilai $\mathrm{t}$ tabel sebesar 1,988. Maka dapat diketahui t hitung 3,501 > $\mathrm{t}$ tabel 1,988 dan nilai signifikan $\quad 0,001$ $<0,05$. Sehingga hipotesis yang berbunyi terdapat pengaruh yang signifikan antara store atmosphere terhadap proses keputusan pembelian diterima $\left(\mathrm{H}_{\mathrm{a}}\right.$ diterima dan $\mathrm{H}_{0}$ ditolak), artinya secara parsial terdapat pengaruh yang signifikan antara store atmosphere terhadap keputusan pembelian.

\section{c. Hasil Uji Regresi Berganda}

Penelitian ini dilanjutkan dengan melakukan pengujian signifikansi model dan interpretasi model regresi.

Tabel 8 Hasil Analisis Regresi Linear Berganda

\begin{tabular}{|l|c|c|}
\hline \multirow{2}{*}{ Model } & \multicolumn{2}{c|}{$\begin{array}{c}\text { Unstandardized } \\
\text { Coefficients }\end{array}$} \\
\cline { 2 - 3 } & B & Std. Error \\
\hline 1 (Constant) & 2.857 & 2.703 \\
Brand_Image & 0.316 & 0.086 \\
Lokasi & 0.174 & 0.051 \\
Store_Atmosphere & 0.196 & 0.056 \\
\hline
\end{tabular}

Sumber : data diolah dari SPSS 24.0, 2017

Berdasarkan hasil yang telah diperoleh dari koefisien regresi di atas, maka dapat dibuat suatu persamaan regresi sebagai berikut:

\section{$Y=2,857+0,316 X_{1}+0,174 X_{2}+$ $0,196 X_{3}+e$}

Dimana :

$\mathrm{Y}=$ Keputusan pembelian

$\mathrm{X}_{1}=$ Brand Image

$\mathrm{X}_{2}=$ Lokasi

$\mathrm{X}_{3}=$ Store Atmosphere 
d. Hasil Uji Koefisien Determinasi $\left(R^{2}\right)$ Tabel 9.

Hasil Koefisien Determinasi (Adjusted R²)

\begin{tabular}{|c|c|}
\hline Model & Adjusted R Square \\
\hline 1 & 0.319 \\
\hline
\end{tabular}

Dapat diketahui koefisien determinasi yang disesuaikan atau $\left(R^{2}\right)$ sebesar 0,319. Hasil ini berarti variabel independen, brand image, lokasi, dan store atmosphere dapat menjelaskan sebesar $31,9 \%$ terhadap variabel dependen yaitu keputusan pembelian, sedangkan sisanya 68\% dijelaskan oleh variabel lain yang tidak disertakan dalam model ini.

Berdasarkan hasil uji regresi linear berganda, maka dapat dihasilkan penelitian sebagai berikut:

a) Pengaruh Brand Image Terhadap Proses Keputusan pembelian

Konsumen Pada Minimarket Kedai Yatim.

Hasil penelitian menunjukan bahwa terdapat pengaruh yang signifikan antara variabel brand image terhadap keputusan pembelian konsumen. Dengan signifikan yaitu $0,000<0,05$ maka hipotesis $\mathrm{H}_{0}$ ditolak, yang berarti terdapat perbedaan yang signifikansi brand image terhadap keputusan pembelian konsumen pada minimarket Kedai Yatim. Sehingga dapat disimpulkan bahwa brand image berpengaruh secara signifikan terhadap keputusan pembelian konsumen pada minimarket Kedai Yatim.

b) Pengaruh Lokasi Terhadap Proses Keputusan pembelian Konsumen Pada Minimarket Kedai Yatim.

Hasil penelitian menunjukan bahwa terdapat pengaruh yang signifikan antara variabel lokasi terhadap keputusan pembelian konsumen. Dengan signifikan yaitu $0,001<0,05$ maka hipotesis $\mathrm{H}_{0}$ ditolak, yang berarti terdapat perbedaan yang signifikansi lokasi terhadap keputusan pembelian konsumen pada minimarket Kedai Yatim. Sehingga dapat disimpulkan bahwa lokasi berpengaruh secara signifikan terhadap keputusan pembelian konsumen pada minimarket Kedai Yatim.

c) Pengaruh Store Atmosphere Terhadap Proses Keputusan pembelian Konsumen Pada Minimarket Kedai Yatim.

Hasil penelitian menunjukan bahwa terdapat pengaruh yang signifikan antara variabel store atmosphere terhadap terhadap keputusan pembelian konsumen. Dengan signifikan yaitu 0,001 $<0,05$ maka hipotesis $\mathrm{H}_{0}$ ditolak, yang berarti terdapat perbedaan yang signifikansi store atmosphere terhadap keputusan pembelian konsumen pada minimarket Kedai Yatim. Sehingga dapat disimpulkan bahwa store atmosphere berpengaruh secara signifikan terhadap keputusan pembelian konsumen pada minimarket Kedai Yatim.

\section{KESIMPULAN DAN SARAN}

Berdasarkan data yang didapatkan dan pengujian yang telah dilakukan terhadap permasalahan, maka dapat diambil kesimpulan sebagai berikut :

1. Brand image, lokasi, dan store atmosphere secara simultan berpengaruh signifikan terhadap keputusan pembelian konsumen pada minimarket Kedai Yatim.

2. Brand image, lokasi, dan store atmosphere secara parsial berpengaruh signifikan terhadap keputusan pembelian konsumen pada minimarket Kedai Yatim.

Berikut adalah berbagai saran yang diajukan oleh peneliti berdasarkan hasil penelitian: (1) Kedai Yatim harus lebih menguatkan citra mereknya sebagai minimarket yang berbasis syariah dan berbeda dengan minimarket lainnya agar dapat lebih menarik konsumen untuk 
berbelanja dan membeli. Dengan cara seperti turut serta dalam kegiatankegiatan kemanusian dan Islami dengan menjadi sponsor ataupun bekerjasama dengan komunitas-komunitas lainnya yang membutuhkan seperti sembako, dll bisa melalui Kedai Yatim. Lokasi juga diperlukan untuk pertimbangan dalam membuka cabang-cabang berikutnya dari kedai yatim agar lebih banyak orang yang tahu dan mengenal kedai yatim sendiri. Selanjutnya store atmosphere yang baik akan membuat konsumen lebih nyaman untuk melihat-lihat dan berbelanja di toko. Sebaiknya Kedai Yatim mempertahankan dan meningkatkan lagi kenyamanan untuk memanjakan dan membuat nyaman konsumen saat berbelanja. Dengan cara pewarnaan yang menarik, pengaturan cahaya dan backsound musik, kebersihan yang harus terus dijaga, dan sirkulasi udara serta aroma yang diharapkan mampu menciptakan perasaan nyaman saat berbelanja; (2) Diharapkan penelitian berikutnya tidak sebatas variabel brand image, lokasi, dan store atmosphere tetapi juga menambahkan variabel lain seperti harga, promosi dan lainnya atau mengembangkan variabel penelitian dengan sampel dan populasi yang lebih besar. Selain itu dapat pula memperluas jangkauan wilayah penelitian seperti mengambil objekobjek ritel modern lainnya yang terdapat di daerah lain. Karena dalam penelitian ini diketahui masih banyak faktor-faktor lain yang mempengaruhi keputusan pembelian konsumen.

\section{DAFTAR PUSTAKA}

Berman B dan, Evans Jr, Retailing management, A Strategic Approach, 8th Edition, New Jersey : Prentice Hall, 2001.

dan . Retail Management, Prentice Hall, New Jersey. 2007. dan . Retail Management: A Strategic Approach, 11th edition, Prentice Hall, New Jersey. 2010.

Eka Syahputra, Denny. Pengaruh Store Atmosphere, Harga dan Lokasi Terhadap Keputusan Pembelian ORE PREMIUM STORE . Jurnal Ilmu dan Riset Manajemen Volume 4, Nomor 11, November 2015.

Gendro,Wiyono. Merancang Penelitian Bisnis dengan Alat Analisis SPSS 17.0 \& Smart PLS 2.0. Percetakan STIM YKPM, Yogyakarta. . 2011.

Ghozali, Imam. Aplikasi Analisis

Multivariate dengan program IBM SPSS 19, Edisi 5, Penerbit: Badan Penerbit Universitas Diponegoro, Semarang. 2011.

Ghozali, Imam, Aplikasi Analisis Multivariate dengan Program SPSS, Badan Penerbit Universitas Diponegoro, Semarang, 2016.

Gujarati, Damodar. Ekonometri Dasar. Terjemahan: Sumarno Zain. Erlangga, Jakarta. 2003.

Isaac Oladep Ph.D, Onigbinde dan Samuel Abimbola M.Sc, Odunlami, 2015, Journal The Influence of Brand Image and Promotional Mix on Consumer Buying Decision - A Study of Beverage Consumers in Lagis State, Nigeria, Department of Business Administration, McPherson University dan Southwestern University Nigeria, Nigeria.

Keller, Kevin Lane. Strategy Brand Management (Building, Measuring and Managing Brand Equity) Global Edition. Fourth Edition. United States: Pearson. 2013.

Kotler, Philip \&Amstrong, Gerry. DasarDasar Pemasaran, Alih Bahasa Oleh: Sindoro dan Markplus, Jilid 1, Indeks, Jakarta. 2003.

2014 ,

Principle of Marketing, 15th edition, Pearson Prentice Hall, New Jersey. 
Philip \& Armstrong, Gary. Principles of Marketing. 16th edition, Pearson. 2016.

Philip \& Keller, Kevin L. Manajemen Pemasaran, Jilid Pertama, Edisi ke-12, Indeksia, Jakarta. 2009.

Management, 14thEdisiGlobal Edition, Pearson Education Limited, New Jersey. 2012.

Levy, Michael and Weitz, A.Barton, Retailing Management, Sixth Edition, Published by McGrawHill/Irwin, New York, 2007.

Levy, Michael \& Weitz, Barton A. Retailing Management,7thEdition, McGraw-Hill Irwin, New York. 2009.

Ma'ruf, Hendri, Pemasaran Ritel, PT Gramedia Pustaka Utama, Jakarta, 2006.

Noor, Juliansyah. Metodologi Penelitian: Skripsi, Tesis, Disertasi, dan Karya

Ilmiah. Kencana, Jakarta. 2011.

Schiffman, L \& Kanuk, L. L. Perilaku Konsumen Edisi 7, Indeks, Jakarta. 2008.

Sugiyono, Metode Penelitian Kuantitatif, Kualitatif dan $\mathrm{R}$ \& D, Alfabeta, Bandung, 2011.

Metode Penelitian Bisnis, CV Alfabeta, Bandung. 2013.

Metode Penelitian dan Pengembangan Research and Development, CV. Alfabeta, Bandung, 2016.

Surachman. Dasar-dasar Manajemen Merek, Bayumedia Publishing, Malang. 2008.

Tjiptono, Fandy. Service Management Mewujudkan Layanan Prima, Edisi 1, Andi Offset, Yogyakarta. 2008. - Manajemen dan Strategi Merek, Penerbit Andi Offset, Yogyakarta. 2011.
Utami, Christina, Strategi Pemasaran Ritel, Edisi Pertama, Indeks, Indonesia, 2008.

Wibowo, Ari. Pengaruh Kualitas Layanan, Harga dan Lokasi Terhadap Keputusan Pembelian di "D'STUPID BAKER" Surabaya. Jurnal Ilmu \& Riset Manajemen Vol. 3 No. 12. 2014.

Yuliana, Imelda. Pengaruh Kualitas Layanan, Citra Merek, dan Lokasi Terhadap Keputusan Pembelian. Jurnal Ilmu dan Riset Manajemen Volume 5, Nomor 6, Juni 2016.

Top Brand Award"Top Brand Award 2016 fase 2"' artikel diakses tanggal 10 Januari 2016 dari http://www.topbrandaward.com/top-brandsurvey/survey result/top_brand_index_2015_fase_ 2

Dream "Kedai Yatim, minimarket mulia" artikel diakses tanggal 11 Januari .2017, dari https://www.dream.co.id/dinar/ke dai-yatim-minimarket-muliadengan-konsep-sedekah160302r.html

"Data industri minimarket, hypermarket, supermarket di Indonesia" artikel diakses tanggal 11 Januari 2017, dari http://duniaindustri.com/downloa ds/data-industri-minimarketsupermarket-hypermarket-diindonesia/

https://www.facebook.com/SenyumBumi-617130991699847/

www.indomaret.co.id/korporat/seputarindomaret/peduli-danberbagi/2014/01/16/sejarah-danvisi/

www.marketeers.com/aprindooptimistis-pertumbuhan-ritel-akanlebih-baik-tahun-2017/ 